\title{
Armed conflict at primary care: challenges for practice and training
}

\author{
Conflito armado na atenção básica: desafios para a formação e prática profissional \\ Conflicto armado en la atención primaria: desafíos para la formación y práctica profesional
}

\section{Raphael Sampaio dos Santos' ORCID: 0000-0001-6250-4712 \\ Lucia Cardoso Mourão' ORCID: 0000-0002-7058-4908 \\ Ana Clementina Vieira de Almeida' ORCID: 0000-0002-9342-6179 \\ Katerine Moraes dos Santos" ORCID: 0000-0002-2064-5207}

'Universidade Federal Fluminense. Rio de Janeiro, Rio de Janeiro, Brazil.

"Universidade Federal do Rio de Janeiro. Rio de Janeiro, Rio de Janeiro, Brazil.

How to cite this article:

Santos RS, Mourão LC, Almeida ACV, Santos KM Armed conflict at primary care: challenges for practice and training. Rev Bras Enferm. 2020;73(2):e20180179. doi: http://dx.doi.org/10.1590/0034-7167-2018-0179

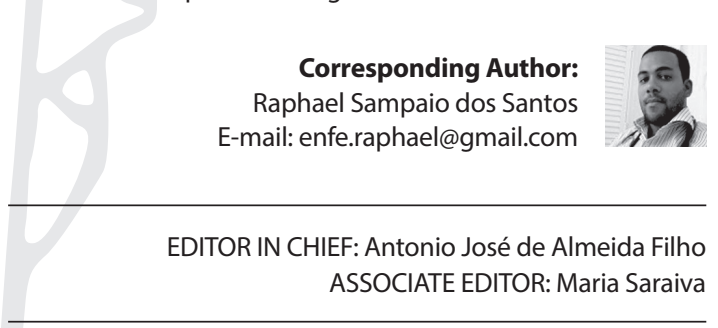

Submission: 19-03-2018

Approval: 22-10-2018

\begin{abstract}
Objectives: to analyze the training of Family Health Strategy health professionals who work in dangerous territories affected by the armed conflict and its consequences in their practice. Methods: a qualitative-intervention research carried out with thirteen health professionals, using as a theoretical-methodological framework the institutional socioclinic. Results: they present and discuss from the analysis of implications of researcher and participants with training, and professional practices and transformations that occurred as intervention work progresses. Final considerations: learning strategies should incorporate empirical and scientifically proven knowledge. Thus, the spectrum of this knowledge would expand dynamically where the situation of violence in its manifestation of armed conflict is a social and political issue and not just a gap in training.

Descriptors: Armed Conflicts; Violence; Professional Training in Health; Professional Practice; Primary Health Care.
\end{abstract}

\section{RESUMO}

Objetivos: analisar a formação dos profissionais de saúde que atuam na Estratégia Saúde da Família em territórios perigosos afetados pelo conflito armado e seus desdobramentos, em sua prática. Métodos: pesquisa-intervenção, com abordagem qualitativa, realizada com treze profissionais de saúde, utilizando como referencial teórico-metodológico a socioclínica institucional. Resultados: são apresentados e discutidos, a partir de duas características da socioclínica institucional: a análise das implicações do pesquisador e participantes com a formação, e as práticas profissionais e as transformações que ocorreram no contexto à medida que o trabalho de intervenção avança. Considerações finais: sinaliza-se que as estratégias de aprendizagem deverão ser pensadas de maneira a incorporar os saberes empíricos e os cientificamente comprovados, para ampliar o espectro desse conhecimento, de maneira dinâmica, onde a situação da violência em sua manifestação de conflito armado seja entendida como uma questão social e política e não apenas uma lacuna na formação. Descritores: Conflitos Armados; Violência; Formação Profissional em Saúde; Prática Profissional; Atenção Básica à Saúde.

\section{RESUMEN}

Objetivos: analizar la formación de los profesionales de salud que actúan en la Estrategia Salud de la Familia en territorios peligrosos afectados por el conflicto armado y sus desdoblamientos, en su práctica. Métodos: investigación-intervención, con abordaje cualitativo, realizada con trece profesionales de salud, utilizando como referencial teórico-metodológico la socioclínica institucional. Resultados: se presentan y discuten, a partir de dos características de la socioclínica institucional: el análisis de las implicaciones del investigador y participantes con la formación, y las prácticas profesionales y las transformaciones que ocurrieron en el contexto a medida que el trabajo de intervención avanza. Consideraciones finales: se señala que las estrategias de aprendizaje deberán ser pensadas para incorporar los saberes empíricos y los científicamente comprobados para ampliar el espectro de ese conocimiento de manera dinámica donde la situación de la violencia en su manifestación de conflicto armado sea entendida como una cuestión social y política y no sólo una laguna en la formación. Descriptores: Conflictos Armados; Violencia; Formación Profesional en Salud; Práctica Profesional; Atención Primaria de Salud. 


\section{INTRODUCTION}

Primary Care is as a set of actions in the individual and collective scope. It covers the promotion, protection, and maintenance of health through prevention of aggravations by early diagnosis of individual treatment and rehabilitation. It is the gateway of the Brazilian Unified Health System (SUS - Sistema Único de Saúde), defined in health policy and guided by the principles of universality, comprehensiveness, equity, accessibility, coordination of care, attachment, longitudinality, humanization, and social participation. It is the main pillar for the change in the organization and care modes, expressed in the Family Health Strategy (FHS) ${ }^{(1)}$.

The National Primary Care Policy (PNAB - Política Nacional da Atenção Básica) ensures coverage of the population and assigns to the family health teams the sanitary responsibility for their territory. It aims at reorganizing traditional biologicist and hospital-centered health care, turning the focus of work towards care for individuals, in the context in which their family nucleus is, thus facilitating comprehensiveness in health teams. It also seeks to reduce inequities in access to health services, and is therefore a model of change in the clinical-care practice of health professionals ${ }^{(1)}$.

Primary Care expansion has produced new ways of generating health and, consequently, an approximation with the nuances of each territory. In the city of Rio de Janeiro, coverage increased from $3.5 \%$ in 2008 to $70.0 \%$ in 2016, through expansion of Family Health teams and implementation of Family Clinics ${ }^{(2)}$.

As a result of this expansion, some Family Health teams were placed in dangerous territories, defined as spaces in which situations may occur that threaten the integrity of the people who live and work there ${ }^{(3)}$. The territories inhabited by the poorest are inclined to manifestations of violence, such as armed conflicts. Urban violence manifests itself in these spaces mainly through armed conflicts between traffickers and police officers ${ }^{(4)}$.

The FHS may suffer a reduction in the potential of its actions by its insertion in settings crossed by social complexities. This may interfere in its effectiveness in replacing the traditional model of health care, and it should be highlighted the consequences of this violence in the practices of health professionals.

In Brazil, social violence is in epidemiological and criminal indicators, showing an unprecedented magnitude and intensity even higher than those observed in countries in a state of war. This violence unequally affects the population, generating different risks not only for individuals of all colors and genders, but also in the social space in which people are inserted $d^{(5)}$. In Brazil, indicators of morbidity and mortality from violence show that most deaths, about $80 \%$, occur in urban centers and are linked to the existence of drug trafficking, traffic accidents, and interpersonal aggression. Concerning interpersonal aggression, between 1980 and 2012, the index grew by around $61 \%$, with a $387 \%$ increase in deaths from firearms. This is even more serious among young people, whose percentage was higher than $460 \%$. This exponential growth is almost exclusively due to homicides, which grew by $556.6 \%{ }^{(5)}$.

Urban violence is a social phenomenon that occurs in the dynamics of a society manifesting itself in different ways. One of them is the armed conflict that can influence the work of health teams, located mostly in the urban peripheries, interfering in the continuity of care for families ${ }^{(6)}$. This is a challenge for health professionals in territories that are often affected by violence ${ }^{(4)}$. Taking this perspective into account, it is necessary to think about the training and practice of professionals who carry out their activities in these violent territories, enabling the acquisition of skills and abilities to articulate the health actions according to the local complexity ${ }^{(7)}$.

With regard to the profile of the health professionals of the FHS, there has been a certain lack of preparation to act in territories where armed conflicts generated by drug trafficking are a constant. In a study carried out by the author, who has served as a nurse in violent territories, this observation supported the hypothesis of a fragile training in the theoretical and practical perspective related to the subject of violence. It was justified the importance of the discussion of this problematic in professional training in health ${ }^{(8)}$.

The training of health professionals has been a reason for constant curriculum changes in order to meet the changes observed in politics, economics, and in ideology, in different historical contexts. The National Curriculum Guidelines (DCN - Diretrizes Curriculares Nacionais), which defined the profile, skills, and competences of different professionals, were established with the objective of ensuring flexibility and quality of the training offered to students. It was based on principles that, in general, refer to the freedom of Higher Education Institutions (HEls) in relation to workload for curriculum renewal. There is also indication of the study fields and teaching-learning experiences; encouragement to the solid general training that allows the undergraduate one to face the challenges of the professional world, as well as in relation to the production of knowledge; promotion of professional and intellectual autonomy; and strengthening of the articulation theory and practice, with valuation of internships and extension activities ${ }^{(9)}$.

DCNs of health undergraduate courses do not specifically address the issue of violence, but aim to guarantee a solid basic training that prepares the undergraduate student to face challenges regarding rapid changes of society, labor market, and conditions of professional practice ${ }^{(9)}$. Although they point out at various times that the student in training must acquire their knowledge in different contexts, these principles hardly apply. Internship fields are always excluded in places where violence can endanger the life of the student and the preceptor, which, in a way, makes the practice of students in these fields unfeasible.

With regard to Primary Care, nursing course's NCDs, published in 2001, do not explicitly prioritize it as the focus of theoreticalpractical learning. They base the necessary training of professionals capable of interfering in health-disease, with responsibility and quality of care offered in different levels of health care through actions of promotion, prevention, protection, and rehabilitation to health from the perspective of care comprehensiveness ${ }^{(10)}$.

In this context, health professionals training does not specify as a necessity the approach to the issue of violence, but explicitly the training according to contents that contribute subsidies to a professional practice capable of meeting the health needs of the population in their social context. In general, professionals who integrate the Family Health teams did not have any approximations with violent territories in their training. This may not have enabled the creation of skills and competencies to act in this reality, besides the knowledge acquired empirically. Detection of risk factors for a particular illness ensures a fundamental analysis of the strategies that support preventive health practices ${ }^{(11)}$. 
A considerable advance in nurses' education is due to the recent discussions held between 2015 and 2017 in 25 education forums, resulting in a draft highlighting some recommendations. These are the greater integration between theory and practice, interdisciplinary training for interprofessional work, participation of service nurses in the training of students in diverse fields of practice. The need for field teaching should include aspects that promote effective professional intervention in the real context of health services. These changes lead us to think that the new training proposed for nurses will bring them closer to the problems of reality, and can bring to debate and reflection the development of professional activities in dangerous territories issue ${ }^{(12)}$.

Considering the perspective of training and professional practice in the context of Primary Care in dangerous territories permeated by violence in its manifestation of armed conflict, it should broaden the reflection on this theme.

\section{OBJECTIVE}

To analyze the training of Family Health Strategy health professionals who work in dangerous territories affected by the armed conflict and its consequences in their practice.

\section{METHOD}

\section{Ethical aspects}

The research was submitted to the Research Ethics Committee of the Hospital Universitário Antônio Pedro/Universidade Federal Fluminense, as a proposing institution. It obeyed the directives and norms regulating researches involving human beings, according to CNS (Conselho Nacional de Saúde - Brazilian Health Board) under Resolution 466/2012. The Ethics in Research Committee of the Municipal Health Office of Rio de Janeiro State, as co-participant institution, approved the research.

\section{Theoretical-methodological framework}

In this study, the Institutional Analysis (IA) was used as a theoretical-methodological framework in the institutional socioclinic aspect proposed by Gilles Monceau. It considers that its methodology can constitute a powerful device capable of promoting reflections and collective debates on the training of professionals and their practices in territories where violence manifests in armed conflicts, taking into account the institutional dynamics. IA began in the 1960s in France, spreading in Brazil in the following decade. As references of French Institutionalism, the authors are René Lourau, Georges Lapassade and Felix Guattari, responsible for the constitution of the foundations of IA and Socioanalysis ${ }^{(13)}$.

It is possible to explain that the studies of Monceau organize a new approach of intervention called institutional socioclinic ${ }^{(14)}$ from the critical analysis of the results of the studies of the aforementioned authors. One of the objectives of this intervention is to generate self-analysis of all participants in a mode of functioning of the subject group. Group-subject and subject-group do not configure mutually exclusive dualities, but are designed as poles, between which any group will oscillate. It is necessary, however, to encourage the conception of a group that operates as a resistance to individualizing and prescriptive modes of relations, surpassing "totalization, unity, generalization, intimidation, and identity [which] has turned it into plus one among other individuals"(15).

The group-subject and the subject-group vector aims to problematize the groups' self-managing potential. For Regina Benevides de Barros, subject-groups receive their law from abroad and are characterized by hierarchy, vertical or pyramidal organization. They conjure up any inscription of death and dissolution; preserve mechanisms of self-preservation, operating by totalizations and by unification. Moreover, the group-subject proposes to think their positions, opening to alterity and creative processes; conjures up totalizations and unifications; allows their practice to lead them into confrontation with their limits, their finitude. They do not seek transcendental guarantees and are defined by the increase in their transversality coefficients ${ }^{(15)}$.

During institutional socioclinic intervention, different moments can be experienced, where the eight characteristics proposed by Monceau can be evidenced. The institutional socioclinic characteristics proposed by Monceau are: "Analysis of the order and the demands; Participation of subjects in the devices; o Work of analyzers; Analysis of transformations as work progresses; Application of refund arrangements; Work of primary and secondary implications; Intention of the production of knowledge; Attention to contexts and institutional interference"(14). It is important to point out that these characteristics are not steps to be followed, but all of them can be contemplated at intervention.

\section{Type of study}

The qualitative study, which gave rise to this article, considered that this format of analysis answers the particular questions, worrying about a level of reality that cannot be quantified. It works with "meanings, motives, aspirations, beliefs, values and attitudes, which corresponds to a deeper space of relationships, processes, and phenomena that cannot be reduced to the operationalization of variables"(16).

\section{Methodological procedures}

\section{Study setting}

The setting chosen was a family clinic in the western region of a municipality in Rio de Janeiro State.

\section{Data source}

Thirteen professionals participated, including seven nurses, two dentists and four doctors. Everyone was developing their activities in their respective teams, in dangerous territories. Their names were replaced by pseudonyms, namely: nurses from 1 to 7; dentists 1 and 2; and doctors from 1 to 4 .

\section{Collection and organization of data}

As a theoretical-methodological proposal, the intervention was used in the molds of the institutional socioclinic in two meetings 
of about two hours each. The data collection took place in 2017. During intervention, a five-issue roadmap was used as a means for the group to collectively address the problem of violence, training, professional practice and preventive and educational measures so that professionals could more safely develop their activities at FHS. In this article, two questions were chosen that allow us to invoke reflections on training and professional practice. The questions are: in the group's view, how was the situation of violence (armed, trafficking in illicit drugs) addressed in their professional training? How does the team organize work in a place with episodes of armed violence? The remaining issues, which are beyond the scope of this article, will be addressed in other publications.

\section{Data analysis}

The speeches were recorded and, after being transcribed, presented to participants in a second meeting, which in the institutional socioclinic is called restitution. At this stage, other issues have emerged giving rise to new reflections and debates. The transcribed data passed through successive readings, at which point the speeches were allocated in the characteristics of institutional socioclinic, where the same speech may belong to more than one characteristic resulting from the interlocking that exists between them. Of the eight characteristics of the institutional socioclinic, those that allowed broadening reflections on the questioning were the analysis of the implications of researcher and participants, and transformations that occur in the group while the intervention work advances.

\section{RESULTS}

Nurses, doctors, and dentists participated in the study, being seven women and six men. Regarding the age group, it ranged from 27 to 45 years. Regarding the average length of training, all had more than seven years of training. As for professional experience time working at Primary Care, there was an average of four years.

The analysis of the statements from the theoretical reference of the institutional socioclinic allowed generating two analytical categories: urban violence and the analysis of the implications of researcher and participants, which deals with the implications and over implementation of the professionals inserted in the context of urban violence, in its manifestation of armed conflict. It also addresses issues related to health education and professional practice; and transformations that occurred in context as the intervention work progresses. Participants are approached by the distance between theory and practice and the importance that spaces outside the academy have in teaching-learning.

\section{Urban violence and analysis of the implications of researcher and participants}

The results of this axis will be presented from the participants' testimony, highlighting their implications and over implementation with professional training and practice. Below is the speech of the researcher, who, together with the other participants, is analyzed during intervention, revealing his professional and personal involvement with the research, work, and training.

I think [...] everyone here participated in this walk [...] I wanted to really thank. And the goal is not even to do an individual interview with any of this, we [...] work has the purpose of analyzing everything that we have experienced so far with these issues of urban violence, and how this disrupts people's work and how we perceive it, has this perception not only in our work processes, but in relation to our training too. (Researcher)

After the speech of the researcher, the debates begin and the participants place their statements where they can perceive their personal and professional implications, referring to the difficulties in inserting themselves in a context permeated by violence, recognizing this gap during their training.

I, frankly, in my academic training [...] never passed me on violence [...] as unit manager, I was taking with them what we could be doing, what would be the best way to be protecting But in academic training, I do not remember at any point of some professor talking about working in the risk area, what has to be done that does not have to be done [...] I do not honestly remember. (Nurse 1)

We talked about violence in the family nucleus [...], but not violence in the territory. (Nurse 2)

The other participant brings to debates how it should be the training in the universities:

I think, well ... that, at the university, you have this psychological and emotional preparation of how to deal with this issue of violence. It is important, because when we are in daily practice, we will be able to apply and have the understanding of what that patient expects of me a certain reaction. That patient, he needs me somehow. For example, I am doing a shutter, not that I am going to keep doing the shutter, I am going to try to promote both emotional and physical shelter for both of us. (Dentist 1)

This testimony reveals the tensions that exist in the daily life of these professionals. They have to think about their own safety and still have the skills and abilities to deal with patients' insecurities, bringing their professional, ideological and affective implications, by putting their demands on the need for education and service institutions to care about the both of the professionals in training and of those who already practice in dangerous territories. Thus, making both institutions responsible for the permanent preparation of these professionals. In this respect they complement the participants below:

[...] I think this part of the academic training is very deficient [...] people from Dentistry had one or two periods. I, in fact, have had one or two periods of this discipline, but it is very superficial. It does not teach you to think of the other, you have an emotional balance that is a set of things. At the time of a shooting, it's something like that [...] you cannot react in a thoughtful way, you end up [...] it's unconscious, you survive [...] / think the aggregation of your values, the experience you've had, helps you with what you're going to do at the time, understand? I think that this part is very deficient inside the universities, during training. (Dentist 1) 
[...] I think the main challenge and deficit of our people is how we prepare psychologically to face this reality that we do not know what it is. When we are in the faculty chair, seeing there together with the other classmates and the professor speak certain disease, certain treatment. So? Arrived on time in the context of the environment that has violence [...] we were not psychologically trained to perform. (Doctor 1)

Nonetheless, while some professionals are able to analyze their implications, others find it more difficult to find themselves overwhelmed with the issue of violence in their manifestation of armed conflict. The following testimonies reveal that the psychic suffering to which these professionals are subjected in the work make them incapable of perceiving the complexity of the violence in its manifestation of armed conflict. In the first testimony, the health professional accepts the risks to the physical and psychic integrity related to the job because it needs the job and the money; and in the second, the professional poses this problem as a simple matter of better adaptation of work:

This issue of not living it during training actually weakens us a lot; and look what we say [...]. Therefore, I think that is it, we suffer this violence. Besides violence in its manifestation of armed conflict, there is an institutional violence that people suffer; it weakens people, yes [...]. Unfortunately, that is it, we need the job, and we need the money. (Researcher)

I think the main here is somehow being able to contribute; it is you organize your work more efficiently. Perhaps in terms of psychological strengthening, it may even contribute to something. Nevertheless, what can contribute more effectively and the organization of work. (Doctor 1)

In the participants' speeches, the collective analysis of the problems related to training and professional practice in a context permeated by violence in its manifestation of armed conflict, have revealed the gaps in training and the crossing of teaching and service institutions in the development of their practices. This evidenced, among others, psychological compromises in the personal and professional lives of these workers.

\section{Transformations that occurred in context as the interven- tion work progresses}

During the development of the intervention in the molds of institutional socioclinic transformations are hardly perceived by the researcher and the participants. However, as the intervention progresses, successive repositioning takes place in the situations and in the institutional dynamics that can be perceived in the changes of position of participants during collective debates. It is therefore important to understand this characteristic as dynamic, present throughout intervention ${ }^{(15)}$.

In following up the debates about training, where they focused on the distance between theory and practice, the participants pointed out that offering only one discipline during training would not be sufficient to prepare them for the development of the practice. What one learns in books and classroom is quickly modified when the health professional comes in contact with the reality:
I think it is very different for you to have something in theory and practice. I think having a discipline in college, approaching theory in practice, is totally different. That's my opinion, I do not know if it would be valid for you to have a specific discipline. (Nurse 3)

The other participant adds:

I think we're trained. At least within my academic training, I did not really have any approach to this, of the influence that armed violence, except for the exception of intrafamily violence, child, woman, [...] family [...] / have the impression that people are trained to practice our professional function in ideal circumstances where we learn in books the lessons such as when we go to the world and start acting in centers whether in the hospital or in Primary Care, we adapt to what we learned in training. But reality quickly changes our practice at least [...] academically [...] at least, this is my experience. (Doctor 1)

Participants begin to rethink who would be responsible for preparing future professionals for the development of their practices in dangerous territories. The testimonies begin to reveal new positions regarding the training, bringing it out of the academic spaces, as it is observed in the speeches:

These are things that the community itself is teaching the health professional how to deal with reality. (Researcher)

However, that is it, I think there is a perspective that universities and schools can bring so that we have this attitude of associating with the other people who are in the territory. Whether they are workers, residents, to build this way of dealing with violence, with this armed violence, with this police violence mainly. but it is certainly not the university that is going to give you the cake recipe. (Researcher)

In the speech below, one can see that changes begin to occur in the way the participant perceives violence: no longer as a local phenomenon, but as a broader phenomenon involving other institutions and organizations.

Another thing that occurs to me now is the following, one of the contexts of the PHC is to strengthen professionals who will act in the risk area, but I do not think in any society of the world violence will be overturned in a matter of a few days, or months, is a matter of mentality, education, health within society over generations ... is not a short-term thing, violence, for many years, will still influence and will affect our practice, will affect the practice education. That is, we have to try to promote change in some way. It is difficult! I am not saying it is an easy thing. (Doctor 1)

During collective debates, the reflections advance by putting training and the development of practices in dangerous territories within the framework of other institutions and organizations. They have brought the need to expand the spaces of dialogue beyond the institutions of education and services also involving users of services and society as a whole.

\section{DISCUSSION}

The results pointed to two characteristics of institutional socioclinic that allowed the analysis of urban violence in its 
manifestation of armed conflict, the training of health professionals, as well as their practices. They are analysis of implications and transformations in the context as the intervention work progresses. Implication is a widely used concept in IA being considered as a:

[...] personal and collective engagement of the researcher in his scientific praxis, due to his family and libidinal history, his past and present positions in the relations of production and class. Also, his socio-political project in action, in such a way that the investment that inevitably results from all this is an integral and dynamic part of all knowledge activity. It presupposes the institutional analyst's self-analysis to understand his motivations to develop in such an area and how these motivations are involved with the organizational project in which he is intervening ${ }^{(17)}$.

The concept of implication denies the presumption of scientific neutrality in research. The myth of the analyst is deconstructed, dismantled. This should get involved, talk about their problems and desires in the field of intervention. Producer and product are linked together ${ }^{(18)}$. The concept of implication is one of the most relevant to Al, referring to our ever-present involvement and even of an unconscious nature with everything we $\mathrm{do}^{(19)}$.

The implication has three dimensions: affective-libidinal, existential, and structural-professional. Considering the complexity of dealing with the issue of violence, since we are all the time involved with institutions that cross us, affective implication of participants may be related to the choice of their profession and their training. Professional structure can be perceived in the accepted in developing its practice in Primary Care and the existential implication with the need to be recognized as professional in the development of its activities. Nonetheless, the fact that they developed their practice in violent territories evidenced the crossing of other institutions, allowing them to analyze the implications with chosen training and the development of their activities at FHS. With regard to the researcher, it can be said that the analysis of their professional and structural implications can be represented by the choice with the research practice, with their work, with interventions that they set out to do, with the theoretical-methodological field and with the society in general ${ }^{(17)}$.

With regard to over implementation, it is necessary to understand this term conceptually. Over implementation is an inability to analyze the implication. This occurs, for example, when the researcher is linked to the institution where the research is carried out, preventing him or her from seeing other important aspects that permeate the context; or when a participant is committed at all costs to the achievement of the purposes of the policies of the health and education organizations to which they belong.

Over implementation is usually perceived during intervention, debates, when the researcher and/or other participants will be able to evaluate their implications and/or their over implementation, which may enrich the study and understanding of reality ${ }^{(19)}$.

In this study, there is over implementation in the testimonies that reveal almost an acceptance or even a banalization of the situation of violence permeated by the armed conflict, disregarding the complexity experienced in their daily life. This reveals the difficulty that some professionals face in facing their daily life in dangerous territory, and it is more comfortable to move the problem to a personal and/or operational dimension in order to avoid further suffering in the development of their activities in that territory.

The results obtained with the analysis of the participants' implications led to an approximation with other studies already carried out on the subject. The first study, carried out with undergraduates of the undergraduate course of a public university, emphasizes that during training the professor should provide teaching-learning situations that boost reflection on problems of reality. It is particularly important that these reflections take place in the learning of collective health, so that when they are inserted in the labor market, they do not feel powerless in situations never experienced during undergraduate course ${ }^{(20)}$.

The second study, carried out with undergraduate students in Nursing, Medicine and Dentistry at Universidade Federal de Santa Catarina, revealed that the insertion of the violence theme during training was addressed superficially. It happened sporadically and showed more physical injuries against people, and not violence related to armed conflicts, and there is a need to broaden the discussions on this issue ${ }^{(21)}$.

It is noteworthy in these results, and in some testimonies of the present study, that the debates about the training of health professionals to work in violent territories are still incipient, focusing on the training centers as those responsible for preparing health professionals for the performance of their duties at those locations.

With regard to what participants would like to receive from educational institutions and services regarding psychological preparation, it was possible to verify with other studies that one must think of ways to fill these gaps in training of future professionals and those who already work in dangerous territories. Research carried out in this area reveals that it is a complex phenomenon to cope with this reality, bringing psychological problems through constant stress, generating emotional exhaustion, impairment in different areas of personal and professional life, and marked reduction of professional satisfaction at work ${ }^{(4)}$.

Another study complements that the violence at work of nursing and other health professionals has repercussions in different areas of health, but mainly in mental health. This increases as professionals feel threatened in a violent work environment, raising the levels of psychological suffering. These repercussions go beyond the workplace, since harmful events also have repercussions on the social and family life of the worker, bringing feelings of irritability, crises of crying, anguish and sadness, with profound repercussions for the health of these workers ${ }^{(22)}$.

Given the results of this study and others, the problems related to the training and practice of health professionals working in dangerous territories were quite similar. The differential of this study is due to the use of institutional socioclinic methodology. It made it possible to analyze the implications and over implementation of participants in a way that recognized the need to broaden the debates about violence and armed conflict in the daily life of their practice begun during data collection. Hopefully, there will be continuity by health professionals. During collective debates, it was also possible to highlight a demand for the training centers and the management of health services. There is a need to have more humanized and effective look during training 
and development of health professionals practices working in dangerous territories.

With respect to the results pointed out in the analysis of the speeches that portray the transformations that occurred in the context, as the intervention work advances, one could observe the concern of participants regarding the distance between theory and practice. These difficulties have been the subject of different studies, whenever the subject training is focus. In all of them, there are gaps between what is learned in training centers and what is found in health services, revealing the difficulties of approximations between health institutions and HEls.

This theme has been highlighted in the discussions held at ABEn (Associação Brasileira de Enfermagem - Brazilian Nursing Association) Education Forums, pointing to the need for changes in curriculum guidelines ${ }^{(12)}$.

In the midst of a setting of changes and increasing demands in the work of health professionals, it is observed that the theoreticalpractical articulation does not occur as it should. This occurred due to problems related to the internship fields, related to the practice of health professionals, lack of physical and material structure, among others, resulting in a distance between theory and practice. This can be identified when the newly trained professional has to face some situations that at first seem new, since they were not experienced during training or occurred in a different way from the professional reality. Some topics and/or procedures, because they do not correspond to the contents proposed in the curriculum, are approached with more superficiality. Even when they are approached, there is hardly an opportunity for them to live in practice during training ${ }^{(21)}$.

The difference of the results obtained in this study is that, in the case of territories where there is armed conflict, it is not viable that they constitute a field of practice. In this case, one cannot say that there is lack of integration theory and practice. It is impossible to carry out this integration considering the risks to the physical and psychological integrity to which the health professionals in their training would be submitted. Therefore, how can we prepare future health professionals to work in the dangerous territories where the FHS units are located? Certainly, there is no single answer, but it is for further study in future studies. Training centers should consider the nuances of this crosssectional theme at different points in training. In this way, there would be more opportunities to discuss the issue of violence in situations of armed conflict throughout the training, enabling the future health professional to work in these places and be more technically and psychologically prepared.

From the results of this study, there is an effort on the part of participants to adapt to the space in which they develop their practical activities. This question is directly related to the new ways of producing knowledge, which does not occur exclusively in the academy, but within the various institutions, whether research or health services ${ }^{(22)}$.

It is evident that when the professional is introduced to the labor market, he should have a new training, or a new construction and structuring of knowledge, acquired from concepts created by their isolated experience during the course, the culture and the philosophy of the new settings where he develops his work as a health professional(23).
By broadening this issue, it can be said that professionals working in dangerous territories need to develop a broad understanding of the place where they develop their practices from individual and social experiences, which requires of them a constant "view and review of reality"(24).

Coherent with other researches, this study brings to the reflection that we must think of implementing innovative pedagogical proposals, searching for a collective construction of knowledge, adding those acquired in educational institutions with others favored by the practice settings and by the community itself. Training should dialogue and bring together scientific and popular knowledge, awakening the exercise of transformation, the construction of instituting knowledge that may be in accordance with the reality of health in force in the country.

This sum of knowledge intends to understand the phenomenon of armed conflict, enabling the search for strategies with different institutions of society, as well as teaching and health service. This would open the way for the situation of violence in its manifestation of armed conflict as a social and political issue, not just as another content to be transmitted, in the training of future health professionals.

\section{Study limitations}

The fact that participants belong to a Family Health team located in the Western region of a municipality in Rio Janeiro State, results point to the understanding of this group, its implications for urban violence, and its expression of armed conflict with its own peculiarities in this context of study. This discussion broaden can be done through other studies, in other realities, with other participants, increasing the evidence on the results found here.

\section{Contributions to the field of Health}

This article sought to bring to debates and reflections the training of health professionals who develop their practice in dangerous territories. The results obtained from the collective analysis of the participants' speeches allowed to broaden the understanding about the subject and to reflect on the necessary theory-practice articulation in health training, highlighting the specificity of violent territories and expansion of training spaces beyond the academy.

\section{FINAL CONSIDERATIONS}

The research made it possible to identify and discuss the professional training received in relation to the promotion of health care in territories where urban violence occurs, based on the study of the current situation experienced by the health professionals in the FHS working in a family clinic located in the area of armed conflict.

Learning strategies should be designed to incorporate empirical and scientifically proven knowledge to extend the spectrum of this knowledge in a dynamic way, where the situation of violence in its manifestation of armed conflict is understood as a social and political issue, not only a gap in training.

It is important to highlight the relevance of the methodology proposed by the institutional socioclinic. It allowed participants 
and researchers to analyze their implications for the issue of violence in dangerous territories, opening space for them to be able to speak freely about their professional training and practice in that context. They revealed, among other issues, their fears, their insecurities and how they are affected technically and psychologically in care they offer to the population.

\section{REFERENCES}

1. Ministério da Saúde (BR). Secretaria de Atenção à Saúde. Departamento de Atenção Básica. Política Nacional de Atenção Básica [Internet]. Brasília: Ministério da Saúde; 2012 [cited 2017 Dec 05]. Available from: http://189.28.128.100/dab/docs/publicacoes/geral/pnab.pdf

2. Soranz D, Pinto LF, Penna GO. Eixos e a Reforma dos Cuidados em Atenção Primária em Saúde (RCAPS) na cidade do Rio de Janeiro, Brasil. Ciênc Saúde Colet. 2016;21(5):1327-38. doi: 10.1590/1413-81232015215.01022016

3. Comitê Internacional da Cruz Vermelha (CICV). Descubra o CICV [Internet]. Genebra: CICV; 2013. [cited 2018 Jan 01]. Available from: https:// www.icrc.org/por/assets/files/other/icrc_007_0790.pdf

4. Machado CB, Daher DV. Violence in the area and its repercussions upon health care actions: descriptive-exploratory study. O Braz J Nurs. 2013;12:674-6. doi: 10.17665/1676-4285.2013v12no

5. Souza ER, Lima MLC. Panorama da violência urbana no Brasil e suas capitais. Ciênc Saúde Colet. 2006;11:1211-22. doi: 10.1590/ S1413-81232006000500011

6. Arantes LJ, Shimizu HE, Merchán-Hamann E. Contribuições e desafios da Estratégia Saúde da Família na Atenção Primária à Saúde no Brasil: revisão da literatura. Ciênc Saúde Colet. 2016;21(5):1499-510. doi: 10.1590/1413-81232015215.19602015

7. Fiúza TM, Miranda AS, Ribeiro MTAM, Pequeno ML, Oliveira PRS. Violência, drogadição e processo de trabalho na Estratégia de Saúde da Família: conflitos de um grande centro urbano brasileiro. Rev Bras Med Fam Comunidade [Internet]. 2011 [cited 2016 Mar 28];6 (18):32-9. Available from: https://www.rbmfc.org.br/rbmfc/article/view/119

8. Santos RS, Mourão LC, Almeida ACV, Brazolino LD, Leite ICM. A formação de profissionais de saúde e a violência no âmbito do território da unidade de saúde da família: uma análise das práticas profissionais. Rev Pró-UniverSUS [Internet]. 2017 [cited 2018 Jan 01]; 8(2):145-7. Available from: http://editora.universidadedevassouras.edu.br/index.php/RPU/article/view/1123

9. Ministério da Educação (BR). Conselho Nacional de Educação. Câmara de Educação Superior. Parecer n 583, de 4 de abril de 2001 a. Orientação para as diretrizes curriculares dos cursos de graduação [Internet]. Brasília: Ministério da Educação; 2001 [cited 2018 Jan 01 ]. Available from: http://portal.mec.gov.br/cne/arquivos/pdf/CES0583.pdf

10. Ministério da Educação (BR). Conselho Nacional de Educação. Câmara de Educação Superior. Parecer no 1133, de 7 de agosto de 2001. Diretrizes Curriculares Nacionais dos Cursos de Graduação em Enfermagem, Medicina e Nutrição [Internet]. Brasília: Ministério da Educação; 2001 [cited 2018 Jan 01]. Available from: http://portal.mec.gov.br/dmdocuments/ces1133.pdf

11. Peres MFT, Ruotti C. Violência urbana e saúde. Rev USP. 2015;(107):65-78. doi: 10.11606/issn.2316-9036.v0i107p65-78

12. Associação Brasileira de Enfermagem (ABEn). ABEn lidera movimento de construção das novas DCN para graduação em enfermagem [Internet]. Brasília: ABEn; 2017 [cited 2018 Jan 01]. Available from: http://www.aben-df.com.br/noticias/2017/aben_lidera_dnc/ABEn\%20 lidera\%20movimento\%20DCN-final-2.pdf

13. L'Abbate S. Análise institucional e saúde coletiva: uma articulação em processo. In: L'Abbate S, Mourão LC, Pezzato LM, organizadoras. Análise Institucional e Saúde Coletiva. São Paulo: Hucitec; 2013. p. 31-88.

14. Barros RB. Grupo: a afirmação de um simulacro. Porto Alegre: Sulina Editora, Editora da UFRGS; 2007.

15. Monceau G. A socioclínica institucional para pesquisas em educação em saúde. In.: L'Abbate S, Mourão LC, Pezzato LM, organizadoras. Análise Institucional \& Saúde Coletiva. São Paulo: Hucitec; 2013. p. 91-103.

16. Minayo MCS. Qualitative analysis: theory, steps and reliability. Ciênc Saúde Colet. 2012;17(3):621-6. doi: 10.1590/ S1413-81232012000300007

17. Barbier R. Pesquisa-ação na instituição educativa. Rio de Janeiro: Zahar; 1985.

18. Lourau R. Objeto e Método da Análise Institucional: um novo espírito científico In: Altoé, S, organizador. Analista institucional em tempo integral. São Paulo: Hucitec; 2004. p. 199-211.

19. Rossi A, Passos E. Análise institucional: revisão conceitual e nuances da pesquisa-intervenção no Brasil. Rev Epos [Internet]. 2014 [cited 2017 Dec 04];5(1):156-81. Available from: http://pepsic.bvsalud.org/scielo.php?script=sci_arttext\&pid=S2178-700X2014000100009

20. Valença CN, Germano RM, Malveiram LMNA, Oliveira AG. Articulating theory and practice in health education in face of the Unified Health System. Rev Enferm UERJ. 2014;22(6):830-5. doi: 10.12957/reuerj.2014.3104

21. Baragatti DY, Audi CAF, Melo MC. Abordagem sobre a disciplina violência em um curso de graduação em enfermagem. Rev Enferm UFSM. 2014;4(2):470-7. doi: 10.5902/2179769211265

22. Bordignon M, Monteiro MI. Violence in the workplace in Nursing: consequences overview. Rev Bras Enferm [Internet]. 2016;69(5):939-42. doi: 10.1590/0034-7167-2015-0133

23. Trevisan DD, Minzon DT, Testi CV, Ramos NA, Carmona EV, Silva EM. Education of nurses: detachment between undergraduation courses 
and professional practice. Ciênc Cuid Saúde. 2013;12(2):331-7. doi: 10.4025/cienccuidsaude.v12i2.19643

24. Moraes RCP, Anhas DM, Mendes R, Frutuoso MFP, Rosa KRM, Silva CRC. Pesquisa participante na estratégia saúde da família em territórios vulneráveis: a formação coletiva no diálogo pesquisador e colaborador. Trab Educ Saúde. 2017;15(1):205-22. doi: 10.1590/1981-7746-sol00035 